\title{
Role of Mandibular Canines in Sex Determination
}

\author{
Miss Bali Sharma ${ }^{1}$, Ms. Ritu Gothwal ${ }^{2}$, Dr.Dhiraj Saxena ${ }^{3}$ \\ Anatomy department, S.M.S.. medical college, rajasthan health science university, india.
}

\begin{abstract}
:
Objective: To establish the effectiveness of mandibular canine index in predicting sex in rajasthan population. Materials and Methods: 100 subjects belonging to rajesthan population (50 males; 50 females) in the age group of 17-25 yrs were included. Impressions were made with alginate and study models prepared with dental stone and living subjects Maximum mesiodistal diameter of mandibular canines and the linear distance between tips of mandibular canines were measured using a Vernier caliper. Observed mandibular canine index $\left(M C I_{o}\right)$ and standerd $M C I$ was calculated as the ratio between the maximum mesiodistal width of mandibular canine and canine arc width.

Results: Left canine exhibited greater sexual dimorphism i.e. 9.05\% as compared with right canine i.e. $8.782 \%$. Sex could be predicted correctly in approximately $80 \%$ of subjects examined.

Conclusion: With the standard MCI it was possible to detect sex in the population of rajesthan to an extent of about $72 \%$. Hence it is considered as a quick, easy and reproducible method for determining the sex of an individual.
\end{abstract}

Keywords: Forensic, mandibular canine index, Canine, mesio-distal dimension, sexual dimorphism, anthropology.

\section{Introduction}

Human body is a miraculous one because of its different structures and different functions .Every structure of the body in its morphology and in histology continuously function and maintain physiological equilibrium . The human body is mainly made of hard tissue in the form of skeletal frame of bone and soft tissue that are present as attachments to the skeletal frame and as organ with in the body.

Teeth being the central component of the masticatory apparatus of the skull are good sources of material for civil and medico-legal identification. In addition, the degree to which they provide resistance to damage in terms of bacterial decomposition, fire, and fracture, it makes them valuable for forensic investigation and research. ${ }^{[1,[2]}$

Bones are the hard structures of the body and have function of the skeletal frame for movements, reservoir of calcium, centre for genesis of blood cells etc. The jaw bone,immovable maxilla and movable mandible are very much concern in the profession of dentistry,as these bones bear the teeth.Teeth are the hardest structure in the body because of its content of calcium appetite crystals a homogenous mass.All the teeth have important charcterstics of having different morphology for resistance to eat, chemicals and microbial attack,different eruption date and possibility of doing restoration for lost structure and failure to regenerate when destructed.All these factors are helpful in personal identification and detection of criminals in criminalization in the field of forensic dentistry.The sign of forensic dentistry deal with relation of teeth and jaws as evidence to law and justice and one of the principle objectives in this field is personal identification and sex determination.

Hence the present study aimed to measure the mesiodistal diameter,incisiocervical length and distance between mesio-labio -incisal angle to distal-labio-incisal angle of four permanent canines two in upper jaw and two in lower jaw in both males and females so as to establish canine measurement variation in sex determination.Further this study includes to measure the intracanine arch distance of mandible in both males and females to correlate the mandibular canine index of lower canine for sex determination. When jaws are at hand, teeth may be used for gender determination with the aid of odontometric analysis. Mandibular canines are found to exhibit the greatest sexual dimorphism amongst all teeth. ${ }^{[3]}$ Studies performed on the lower canines using the ratio between the maximum crown width and inter-canine width, resulting in a mandibular canine index (MCI), have shown an ability to determine gender with an accuracy of $84.3 \%$ in males and $87.5 \%$ in females and $83.3 \%$ in males and $81 \%$ in females by comparing the observed MCI with a standard MCI value ${ }^{[4][5]}$ respectively.

\section{Aims And Objectives}

1. To identify role of mandibular canines in sex determination.

2. To find out mandibular canines index and sexual dimorphism methods for sex determination. 


\section{Material And Methods}

The Present study was conducted on 100 adult students(100 subjects 50 males and 50 females) age groups of 17 to 21 years were selected as attrition is minimal in this age group.The study was conducted on the student of government SMS medical college Jaipur(rajasthan).

\section{Methodology}

The measurement divided into two groups .Group A taken as male and group B taken as female,according to our work there are two methods -

- Mandibular canines index

-Observed mandibular canine index

-Standard mandibular canine index.

- Sexual dimorphism

\section{Material}

All the measurements were done using following materials

1. Stainless steel vernier caliper

2. Stainless steel flexible tape

3. Divider with a fixing device.

For formation of cast material-

1 Alginate powder

2 Dental stone

3 Perforated tray

4 Rubber bowel

5 Spatula

\section{Method}

With the help of sliding caliper and fiexible steel tape the following measurements were taken to the nearest millimeter.

\section{Right Mandibular Canine Width}

Maximum width of a right canine is measured from distal margin of canine to mesial surface of canine.

\section{Left Mandibular Canine Width}

Maximum width of a left canine is measured from distal margin of canine to mesial surface of canine.

Both the canines width taken-

- Intra orally

- On the cast of same subject.

\section{Intercanine Distance}

Maximum intercanine distance is measured from the tip of right canine to tip of left canine in lower jaw. Intercanine distance are taken

- Intra orally

- On the cast of same subject.

Mandibular canine index $=\frac{\text { mesio distal crown width of mandibular canines }}{\text { interanines distanc }}$

\section{Sexual Dimorphism}

sexual dimorphism was calculated by using formula given by gran and lewis as follows-

Sexual dimorphism $\frac{\mathrm{xm}}{\mathrm{xf}} \times 100$

$\mathrm{Xm}=$ mean value of males

$\mathrm{Xf}=$ mean value of females

- Observed mandibular canine index $=\frac{\text { mesio distal crown width of mandibular canines }}{\text { intercanine distance }}$

- Standard mandibular canine index $=\frac{(\text { mean male } \mathrm{MCI}+\mathrm{SD})+(\text { Mean female } \mathrm{MCI}+\mathrm{SD})}{2}$

Data analysis

Thus data was collected on a pre design proforma and was analysed using $\mathrm{Z}$ test.

Observation

The dats's and results were compiled and arranged in the tables and subjected to statistical analysis. 
The differences in the mean values of males and females were analyzed statistically using $\mathrm{Z}$ test and their significance is shown in table No 3,6,7,8,9 by observing the tables it is clear that left \& right canine width in one male or female and some measurement on orally or cast. There values are insignificant between the males and females.

The observations should that in case of the manibular canine index method mean for males is .28 \& for female .27 same on orally or casts.

In my study there were 50 males \& 50 females. Index and manibular canine method for both values are slightly significance.

Where comparasion between right \& left canine width of cast \& Intra oral in male it was RCW $7.23 \pm 0.17$ on cast $\&$ slightly differ in oral it was $7.23 \pm 0.16$ and left canine width (LCW) $7.22 \pm 0.13$ on cast \& $7.22 \pm 0.14$ intra oral so there was no significance $\&$ p-value $>.05$ as shown in Table No-I.

Other Comparasion between right \& left conine width of cast \& intra oral in female it was $6.60 \pm .011 \mathrm{RCW}$ on cast \& $6.60 \pm .011$ on cast \& LCW $6.58 \pm 0.10$ on cast \& $6.57 \pm 0.10$ Intra-oral. There was no significance \& P-value > .05. as shown in table No -II.

Compare of Inter canine distance of cast \& Intra oral in males \& females indicates that values higher in males as compare to females.

It was $25.25 \pm 1.32$ on cast for male \& $24.00 \pm 0.75$ on cast for female $25.23 \pm 1.36$ for male on oral $\& 23.97 \pm 0.79$ for female on oral and $\mathrm{P}$ value $<.001$, it was highly significance as shown in Table No \& graph No-3.

Comparison between RCW of cast \& Intra oral according to sex for male $7.23 \pm 0.17$ on cast \& $6.60 \pm$ 0.11 for female. It was7.23 \pm 0.16 Intra oral for male $\& 6.59 \pm 0.11$ for female $\&$ P-value $<.001$, it was highly significance as shown in table No -6 .

Comparison between mean \pm sd of left canine width of cast \& intra oral according to sex it was $7.22 \pm$ 0.13 for male on cast $6.58 \pm 0.09$ for female $\& 7.22 \pm 0.14$ for male on oral $\& 6.57 \pm 0.10$ for female. P-value $<.001$.

It was highly significance as shown in table No-7 mean \pm sd of right mandibular canine Index of cast $\&$ intra-oral according to sex for male $0.28 \pm 0.013 \& .27 \pm 0.11$ for female on cast. It was $.28 \pm 0.014$ for male \& $.27 \pm 0.011$ for female intra oral \& P-value $<.01$, it was highly significance as shown in table No. -8 mean \pm sd of left mandibular canine index of cast $\&$ intra oral according to sex.

It was $0.28 \pm .010$ for males on cast $\& .27 \pm 0.011$ for females $\& .28 \pm 0.010$ for males $\& .27 \pm 0.011$ for female P-value <.01. it was highly significance as shown in table No.-9 mean \pm sd of right \& left mandibular canine index of cast $\&$ intra-oral in malRMCI - $.28 \pm 0.013$ for males on cast and $.28 \pm 0.014$ intra oral \& LMCI -.28 \pm 0.010 on cast \& $.28 \pm 0.010$ on intra oral for males. P-value $>.05$ it was no significance as shown in Table No. -4 mean \pm sd of right $\&$ left MCI of cast \& intra oral in female it was RMCI .27 \pm 0.011 on cast LMCI. P-value >.05 it was No-significance as shown in Table No.-5

Table No. 1: Mean \pm Sd of Right $\&$ Left canine width of cast $\&$ intra oral in male

\begin{tabular}{|l|l|l|l|l|}
\hline \multirow{2}{*}{ Parameters } & Mean \pm Sd & P-value & Significance \\
\cline { 2 - 5 } & Right canine width & Left canine width & & \\
\hline Cast & $7.23 \pm 0.17$ & $7.22 \pm 0.13$ & $>.05$ & NS \\
\hline Intra oral & $7.23 \pm 0.16$ & $7.22 \pm 0.14$ & $>.05$ & NS \\
\hline
\end{tabular}

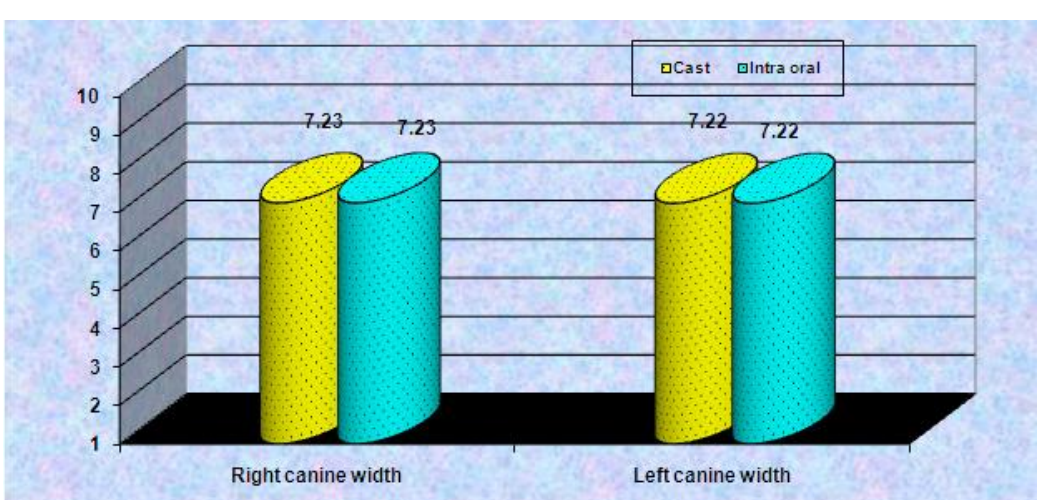

Table No I \& graph indicates that width of right $\&$ left canine width of cast $\&$ intra oral in males there is no significance.

Table No. 2 Mean + Sd of Right \& Left canine width of cast \& intra oral in female

\begin{tabular}{|l|l|l|l|l|}
\hline \multirow{2}{*}{ Parameters } & Mean \pm Sd & \multirow{2}{*}{ P-value } & \multirow{2}{*}{ Significance } \\
\cline { 2 - 4 } & Right canine width & Left canine width & & \\
\hline Cast & $6.60 \pm 0.11$ & $6.58 \pm 0.10$ & $>.05$ & NS \\
\hline Intra oral & $6.59 \pm 0.11$ & $6.57 \pm 0.10$ & $>.05$ & NS \\
\hline
\end{tabular}




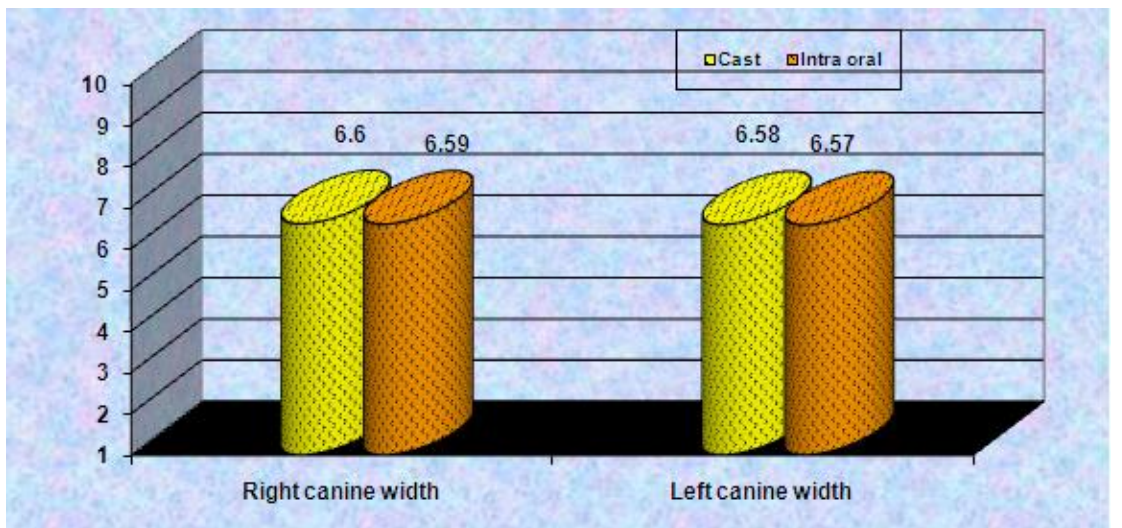

Table No. 3: Mean + Sd of Inter canine distance of cast \& intra oral according to sex

\begin{tabular}{|l|l|l|l|l|}
\hline \multirow{2}{*}{ Parameters } & \multicolumn{2}{|l|}{ Mean $\pm \mathrm{Sd}$} & P-value & Significance \\
\cline { 2 - 5 } & $\begin{array}{l}\text { Male } \\
(\mathrm{n}=25)\end{array}$ & $\begin{array}{l}\text { Female } \\
(\mathrm{n}=25)\end{array}$ & & \\
\hline Cast & $25.25 \pm 1.32$ & $24.00 \pm 0.75$ & $<.001$ & HS \\
\hline Intra oral & $25.23 \pm 1.36$ & $23.97 \pm 0.79$ & $<.001$ & HS \\
\hline
\end{tabular}

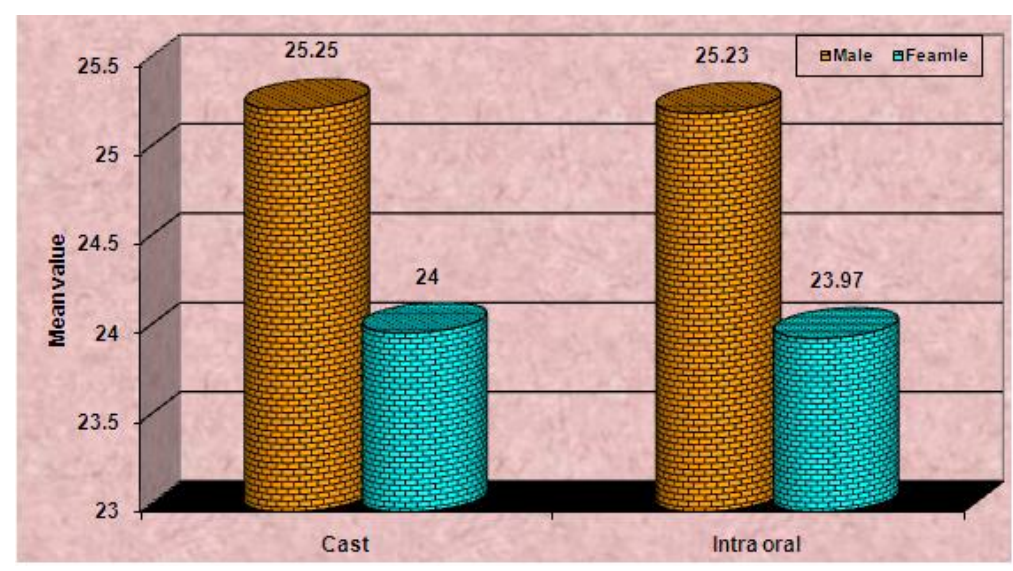

Table No 3- graph indicates compare of inter canine distance of cast \& Intra oral in males \& females indicates that values higher in males as compare to females.

Table No. 4: Mean \pm Sd of Right \& Left mandibular canine index of cast \& intra oral in male

\begin{tabular}{|l|l|l|l|l|}
\hline Parameters & Mean \pm Sd & P-value & Significance \\
\cline { 2 - 4 } & $\begin{array}{l}\text { Right mandibular canine } \\
\text { index }\end{array}$ & $\begin{array}{l}\text { Left mandibular canine } \\
\text { index }\end{array}$ & & \\
\hline Cast & $0.28 \pm 0.013$ & $0.28 \pm 0.010$ & .05 & NS \\
\hline Intra oral & $0.28 \pm 0.014$ & $0.28 \pm 0.010$ & $>.05$ & NS \\
\hline
\end{tabular}

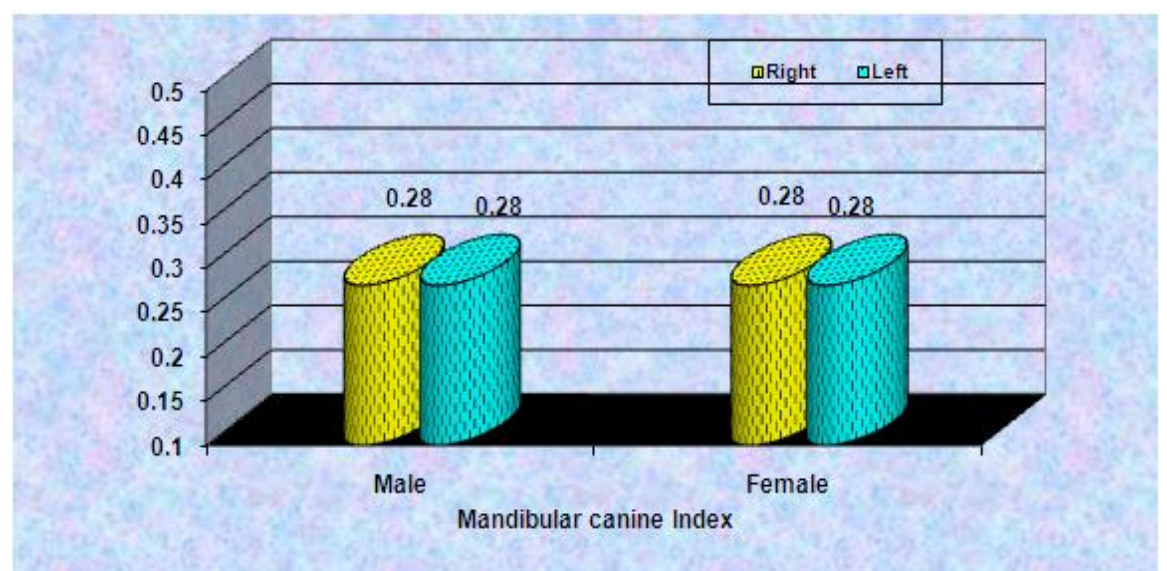

Table No. $4 \&$ graph Indicates that there in the value of right $\&$ left mandibular canine index of cast $\&$ intra oral in male $\&$ the is no any significance. 
Table No. 5: Mean \pm Sd of Right \& Left mandibular canine index of cast \& intra oral in female

\begin{tabular}{|c|c|c|c|c|}
\hline \multirow[t]{2}{*}{ Parameters } & \multicolumn{2}{|l|}{ Mean + Sd } & \multirow[t]{2}{*}{$\mathrm{P}$-value } & \multirow[t]{2}{*}{ Significance } \\
\hline & $\begin{array}{l}\text { Right mandibular canine } \\
\text { index }\end{array}$ & $\begin{array}{l}\text { Left mandibular canine } \\
\text { index }\end{array}$ & & \\
\hline Cast & $0.27 \pm 0.011$ & $0.27 \pm 0.011$ & $>.05$ & NS \\
\hline Intra oral & $0.27 \pm 0.011$ & $0.27 \pm 0.011$ & $>.05$ & NS \\
\hline
\end{tabular}

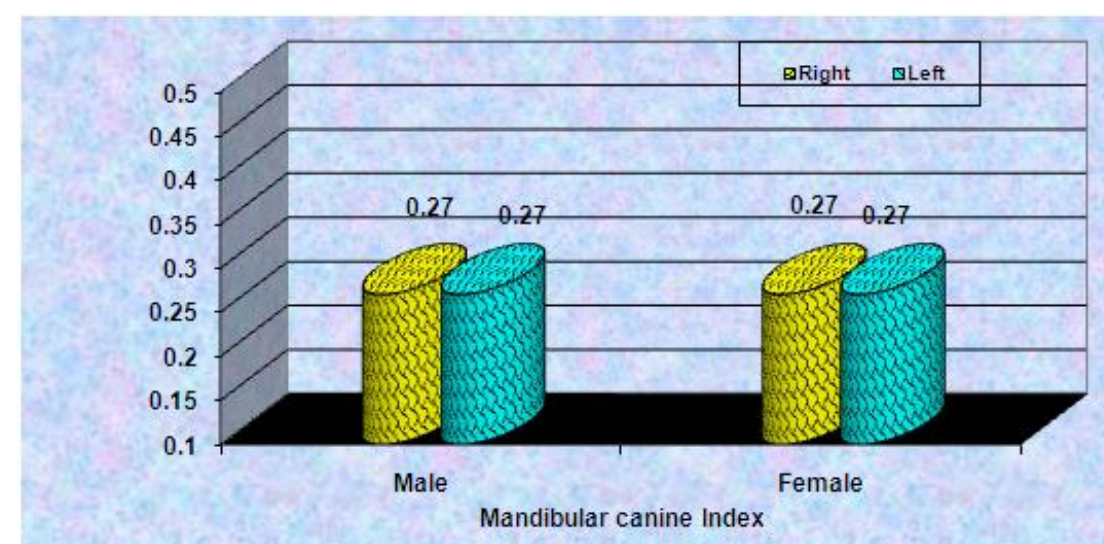

Table No. $5 \&$ graph Indicates that there is no significance between the right \& left mandibular canine index of cast \& intra oral in femal

Table No. 6 Mean \pm Sd of Right canine width of cast \& intra oral according to sex

\begin{tabular}{|l|l|l|l|l|}
\hline \multirow{2}{*}{ Parameters } & Mean \pm Sd & P-value & Significance \\
\cline { 2 - 5 } & $\begin{array}{l}\text { Male } \\
(\mathrm{n}=25)\end{array}$ & $\begin{array}{l}\text { Female } \\
(\mathrm{n}=25)\end{array}$ & & \\
\hline Cast & $7.23 \pm 0.17$ & $6.60 \pm 0.11$ & $<.001$ & HS \\
\hline Intra oral & $7.23 \pm 0.16$ & $6.59 \pm 0.11$ & HS \\
\hline
\end{tabular}

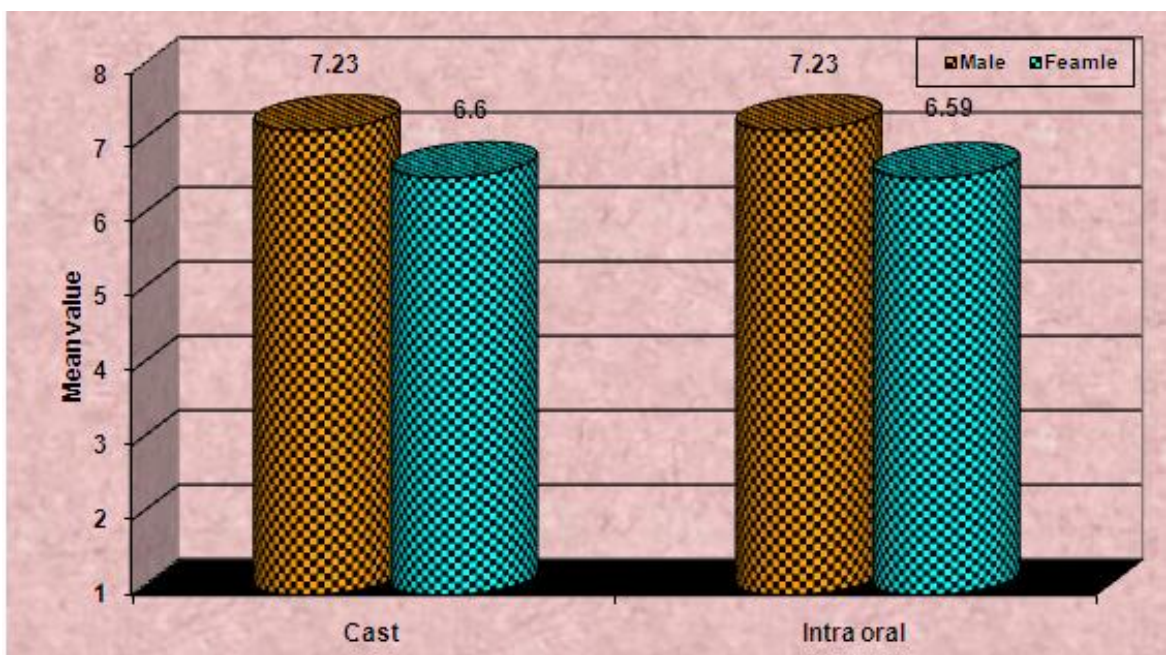

Table No $6 \&$ graph indicates there is comparison of right canine width of cast $\&$ intra oral in males $\&$ females indicates that values higher in males as compare to female

Table No.7: Mean \pm Sd of Left canine width of cast \& intra oral according to sex

\begin{tabular}{|c|c|c|c|c|}
\hline \multirow[t]{2}{*}{ Parameters } & \multicolumn{2}{|l|}{ Mean $+\mathrm{Sd}$} & \multirow[t]{2}{*}{ P-value } & \multirow[t]{2}{*}{ Significance } \\
\hline & $\begin{array}{l}\text { Male } \\
(\mathrm{n}=25)\end{array}$ & $\begin{array}{l}\text { Female } \\
(\mathrm{n}=25)\end{array}$ & & \\
\hline Cast & $7.22+0.13$ & $6.58+0.09$ & $<.001$ & HS \\
\hline Intra oral & $7.22 \pm 0.14$ & $6.57 \pm 0.10$ & $<.001$ & HS \\
\hline
\end{tabular}




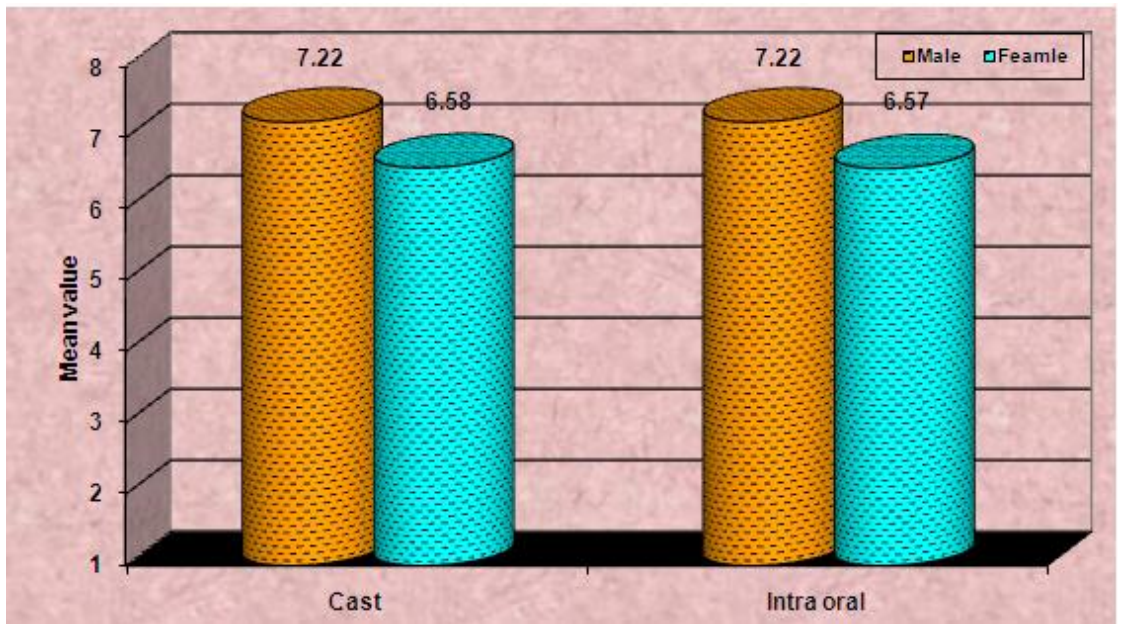

Table No $7 \&$ graph indicates comparasion of left canine width of cast \& intra oral in males \& females, indicates that values highly significance $\&$ higher in males as compare to females.

Table No.8: Mean \pm Sd of Right mandibular canine index of cast $\&$ intra oral according to sex

\begin{tabular}{|l|l|l|l|l|}
\hline Parameters & Mean \pm Sd & P-value & Significance \\
\cline { 2 - 3 } & $\begin{array}{l}\text { Male } \\
(\mathrm{n}=25)\end{array}$ & $\begin{array}{l}\text { Female } \\
(\mathrm{n}=25)\end{array}$ & & \\
\hline Cast & $0.28 \pm 0.013$ & $0.27 \pm 0.011$ & $<.01$ & Sig \\
\hline Intra oral & $0.28 \pm 0.014$ & $0.27 \pm 0.011$ & $<.01$ & Sig \\
\hline
\end{tabular}

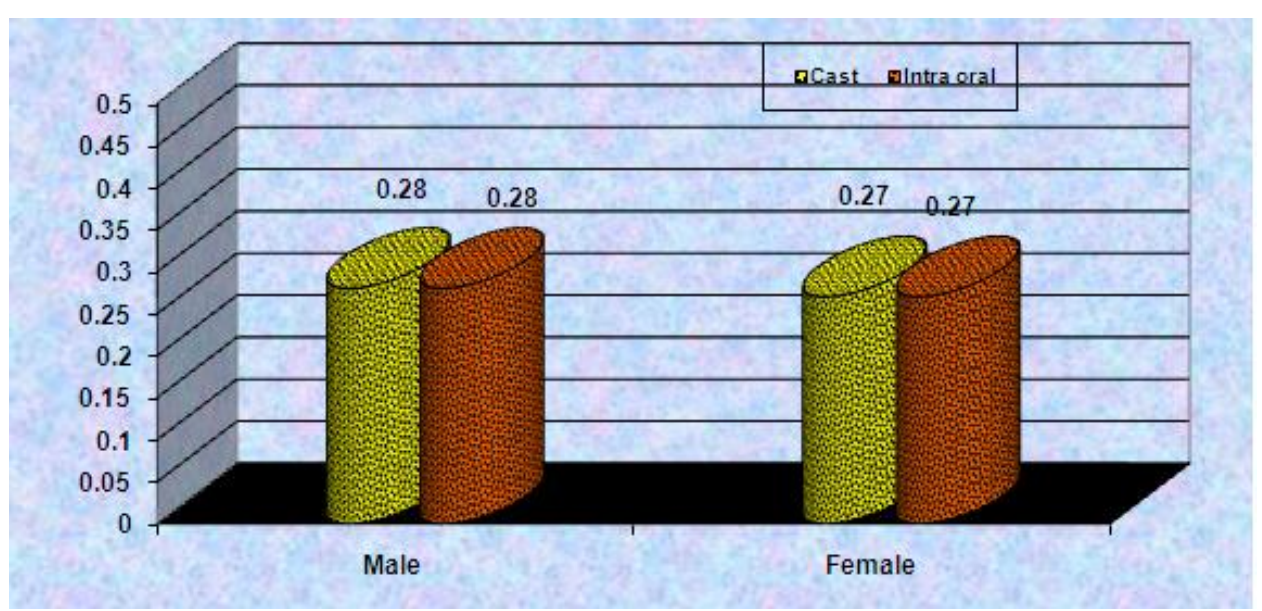

Table No 8 \& graph indicates comparison of right mandibular canines index of cast $\&$ intra oral in males \& females indicates that values higher in males as compare to female.

Table No. 9: Mean \pm Sd of Left mandibular canine index of cast $\&$ intra oral according to sex

\begin{tabular}{|l|l|l|l|l|}
\hline \multirow{2}{*}{ Parameters } & Mean \pm Sd & P-value & Significance \\
\cline { 2 - 5 } & $\begin{array}{l}\text { Male } \\
(\mathrm{n}=25)\end{array}$ & $\begin{array}{l}\text { Female } \\
(\mathrm{n}=25)\end{array}$ & & \\
\hline Cast & $0.28 \pm 0.010$ & $0.27 \pm 0.011$ & $<.01$ & Sig \\
\hline Intra oral & $0.28 \pm 0.010$ & $0.27 \pm 0.011$ & $<.01$ & Sig \\
\hline
\end{tabular}




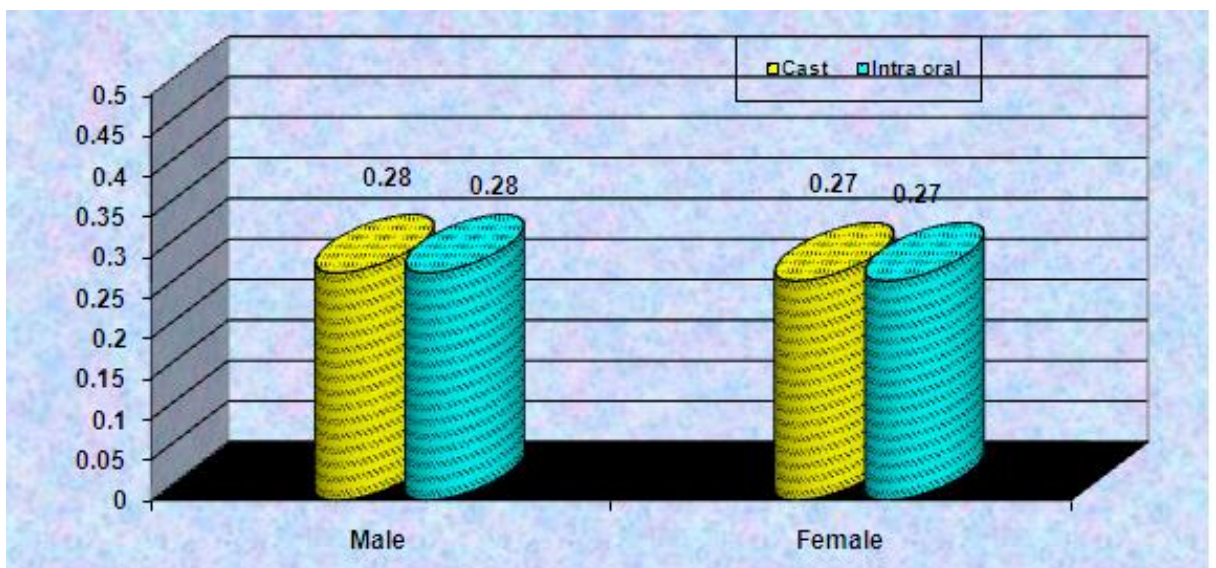

Table No $9 \&$ graph indicates there is difference or comparison of left mandibular canine index of cast $\&$ intra oral in males \& females indicates that values higher in males as compare to females.

\section{Discussion}

Both the maxillary and mandibular canines are very much similar to each other their functions are closely related.All the four canines are justifiably called as corner stones of the arches they are also called cuspates,eye teeth and very rarely also as fangs.In both jaws canine is the third tooth from mid line on both sides. The mesial surface of the canine is in contact with the distal surface of lateral incisor.The distal surface of canine is in contact with the mesial surface of the first premolar.They are longest of the permanent teeth(approximately $27 \mathrm{~mm}$ ) the crowns are almost equal to central incisor in length and the roots are longer than all other teeth.Canine separation is influenced by the width of the incisors and canines, and significant correlations were found in both sexes between canine separation and canine widths. ${ }^{[6]}$

The present study establishes the existence of a definite statistically significant sexual dimorphism in mandibular canines. It is consistent with the findings of Hashim and Murshid ${ }^{[7]}$ who conducted a study on Saudi males and females in the age group of 13-20 years and found that only the canines in both jaws exhibited a significant sexual difference while the other teeth did not. ${ }^{[7]}$ Similar findings were given by Lew and Keng ${ }^{[8]}$ in their study on an ethnic Chinese population with normal occlusions. ${ }^{[8]}$ The percentage dimorphism (the percent to which the tooth size of males exceeded that of females) expressed as the male/female ratio minus 1.00 was also calculated and according to the present study the left mandibular canine was found to exhibit greater dimorphism $(9.058 \%)$. Garn and Lewis ${ }^{[4]}$ and Lysell and Myrberg ${ }^{[9]}$ concluded that the mandibular canine exhibited the greatest sexual dimorphism amongst all teeth $(6.47 \%$ and $5.7 \%$ respectively). Nair et al. ${ }^{[10]}$ in their study on South Indian subjects reported that the left mandibular canine exhibited a sexual dimorphism of $7.7 \%$ and the right mandibular canine $6.2 \%$. Mandibular canines are found to exhibit the greatest sexual dimorphism among all teeth. ${ }^{[4]}$ The notable difference between canine in determining sex was noted to be due to the influence of the Y chromosome which was not uniform in all teeth. On the other hand, the X-linked genetic influence on tooth width was rather uniform for all teeth. ${ }^{[4]}$ When jaws are at hand, teeth may be used for gender determination with the aid of odontometric analysis. Mandibular canines are found to exhibit the greatest sexual dimorphism amongst all teeth. ${ }^{[11]}$ The fact that most teeth complete development before skeletal maturation makes the dentition a valuable sex indicator, particularly in young individuals. ${ }^{[12]}$

These findings indicate that mandibular canines can be considered as the 'key teeth' for personal identification. ${ }^{[13]}$

\section{Conclusion}

After a detailed study and comparision of our work with other workers.It can be conducted that diagnostic efficacy of mandibular canine index and sexual dimorphism method given by garn and lewis very important for sexual dimorphism by these methods we can easily determined the role of mandibular canine in sexual dimorphism the relevant values always higher in males as compare in females.Continued study over a period of time in a defined area will definitely help in establishing the anthropometric standards.

\section{Acknowledgements}

Event if I had been a scholar of all the languages in the world. It would not have been possible for me to pen down my deep respect and gratitude for my esteemed teacher and learned guide DR.DHIRAJ SAXENA (Professor) Department of Anatomy SMS Medical College and Hospital Jaipur. 
I Consider myself greatly blessed to have got the opportunity to work under his able guidance. He is a source of inspiration for all those working with him who helped, \& guided me at every step in carrying out this study.

\section{References}

[1]. Acharya BA, Mainali S. Univariate sex dimorphism in the Nepalese dentition and the use of discriminant functions in gender assessment. Forensic SciInt 2007;173:47-56.

[2]. Vahanwahal SP, Parekh DK. Study of lip prints as an aid to forensic methodology. J Ind Dent Assoc 2000;71:269-27.

[3]. Garn SM, Lewis AB, Swindler DR, Kerewsky RS. Genetic control of sexual dimorphism in tooth size. J Dent Res 1967;46:963-72.

[4]. Rao NG, Rao NN, Pai ML, Kotian MS. Mandibular canine index: A clue for establishing sex identity. Forensic SciInt 1989;42:24954.

[5]. Yadav S, Nagabhushan D, Rao BB, Mamatha GP. Mandibular canine index in establishing sex identity. Indian J Dent Res 2002;13:143-6.

[6]. Anderson DL, Thompson GW. Interrelationships and sex differences of dental and skeletal measurements. J Dent Res 1973;52:431 8 .

[7]. Hashim HA, Murshid ZA.Mesiodistal tooth width: A comparison between Saudi males and females. Egypt Dent J.1993;39:343-6.

[8]. Lew KK, Keng SB. Anterior crown dimensions and relationship in an ethnic Chinese population with normal occlusions. AustOrthod J 1991;12:105-9.

[9]. Lysell L, Myrberg N. Mesiodistal tooth size in the deciduous and permanent dentitions. Eur J Orthod 1982;4:113-22.

[10]. Nair P, Rao BB, Annigeri RG. A study of tooth size, symmetry and sexual dimorphism. J Forensic Med Toxicol 1999;16:10-3.

[11]. Kaushal S, Patnaik VV, Agnihotri G. Mandibular canines in sex determination. J AnatSoc India 2003;52:119-24.

[12]. Lund H, Mörnstad H. Gender determination by odontometrics in a Swedish population. J Forensic Odontostomatol 1999;17:30-4.

[13]. Dahlberg AA. Dental traits as identification tools. Dent Prog 1963;3:155-60. 